\title{
PENINGKATAN KEMAMPUAN MENULIS TEKS FABEL DENGAN PEMBELAJARAN BERBASIS PORTOFOLIO PADA SISWA KELAS VIII SMP NEGERI 1 PONDOK KELAPA BENGKULU TENGAH
}

\author{
Santi Yuliani \\ yuliani.santi@gmail.com \\ Guru SMP Negeri 1 Pondok Kelapa Bengkulu Tengah
}

\begin{abstract}
The purpose of this study to describe comprehensively the increase in the Ability to Write Text Fabel with Portfolio Based Learning to Students of Class VIII SMP Negeri 1 Pondok Kelapa Bengkulu Tengah. The method used is classroom action research. Sources of data obtained through eighth grade students worksheet F. Data collection techniques in this study is the testing techniques and nontes (observation, journals, and interviews). This research was conducted in three cycles. First cycle consisted of 2 meetings, the second cycle consists of two sessions, and the third cycle comprises one meetings. The test results of this study indicate that an increased ability to write text fable in students. The average value of the class in the first cycle of 63.6 (enough) with a passing rate of $27 \%$, increased in the second cycle with an average of 70 (good) with a passing rate of $56.7 \%$. Then increased again in the third cycle, which amounted to 76 (excellent) with a passing rate reached $86.7 \%$.
\end{abstract}

Keywords:Text Fabel, Writing, Portfolio

\section{PENDAHULUAN}

Pembelajaran Bahasa Indonesia di sekolah bertujuan untuk membantu siswa dalam menguasai empat keterampilan berbahasa, yakni keterampilan membaca, menyimak, berbicara, dan menulis. Keempat keterampilan tersebut memiliki fungsi dan manfaatnya masing-masing, serta sangatlah penting untuk dikuasai oleh siswa di sekolah. Dengan menguasai keempat keterampilan berbahasa tersebut, nantinya siswa diharapkan dapat memahami dan mengaplikasikannya di dalam kehidupan sehari-hari.

Salah satu dari empat keterampilan berbahasa yang sangat penting untuk dikuasai oleh siswa adalah keterampilan menulis. Keterampilan menulis merupakan salah satu keterampilan berbahasa yang harus diajarkan kepada siswa. Selain itu, keterampilan menulis juga memiliki peranan yang sangat penting di dalam kehidupan, dengan menulis, seseorang mampu menuangkan segala perasaan, ide maupun gagasan yang ia miliki ke dalam sebuah tulisan. Menulis di dalam pelaksanaannya membutuhkan kreatifitas dan imajinasi yang tinggi.

Berdasarkan Kurikulum 2013, pembelajaran Bahasa Indonesia menggunakan pembelajaran yang berbasis teks. Ada beberapa alasan yang dikemukakan mengapa pembelajaran Bahasa Indonesia pada Kurikulum 2013 menggunakan pembelajaran yang berbasis teks. Alasan tersebut dikemukakan oleh Mahsun (2014: 97), diantaranya yaitu: "Pertama, melalui teks kemampuan berpikir siswa dapat dikembangkan; kedua, materi 
pembelajaran berupa teks lebih relevan dengan karakteristik Kurikulum 2013 yang menetapkan capaian kompetensi siswa yang mencakupi ketiga ranah pendidikan: Pengetahuan, keterampilan, dan sikap."

Tujuan ditetapkannya pembelajaran berbasis teks pada Kurikulum 2013 untuk mata pelajaran Bahasa Indonesia tentunya untuk menuntut para siswa agar mampu menulis berbagai jenis teks yang telah mereka pelajari dengan baik selama proses belajar mengajar berlangsung, baik pada kelas VII, VIII, dan IX. Selain itu, pembelajaran berbasis teks pada Kurikulum 2013 juga bertujuan untuk melatih kreativitas siswa dalam proses pembelajaran Bahasa Indonesia. Dengan pembelajaran yang berbasis teks ini, diharapkan siswa dapat memiliki keterampilan atau kemampuan baik dalam hal menulis, membaca, menyimak maupun berbicara.

Teks fabel merupakan sebuah cerita fiksi yang di dalamnya bercerita mengenai kehidupan hewan serta mengandung nilai-nilai moral. Tujuan yang ingin dicapai dalam pembelajaran menulis teks fabel ini adalah siswa mampu menyusun teks fabel sesuai dengan karakteristik teks yang akan dibuat baik secara lisan maupun tulisan, oleh sebab itu, dalam pembelajaran guru hendaknya dapat membimbing dan melatih siswa untuk dapat menuangkan segala ide, gagasan, imajinasi serta pengetahuannya ke dalam sebuah bentuk tulisan, terutama dalam bentuk tulisan teks fabel.

Berdasarkan hasil observasi awal dan diskusi bersama guru di SMP Negeri 1 Pondok Kelapa Bengkulu Tengah, diperoleh informasi bahwa rata-rata kemampuan menulis siswa kelas VIII masih tergolong rendah. Hal ini dapat dilihat dari rata-rata nilai menulis siswa yang masih belum mencapai standar kelulusan. Salah satunya yaitu dalam menulis teks fabel. Kemampuan menulis teks fabel siswa di kelas VIII pada semester lalu rata-rata masih di bawah standar kelulusan. Dari seluruh kelas VIII, nilai menulis siswa rata-rata masih sekitar $30 \%$ yang telah memenuhi standar kelulusan.

Ada beberapa faktor yang menyebabkan kemampuan menulis teks fabel siswa belum mampu mencapai nilai standar kelulusan. Faktor tersebut diantaranya adalah: 1) Siswa kurang memahami materi dengan baik, terutama materi tentang strukturstruktur pembangun sebuah teks dan unsur kebahasaan dari teks tersebut, 2) Siswa sulit menentukan tema atau ide yang akan diangkat menjadi sebuah tulisan, 3) Kurangnya pemahaman siswa mengenai penggunaan EYD, 4) Kegiatan atau pelajaran menulis masih dianggap sulit oleh sebagian siswa, karena ketidakbiasaan mereka di dalam menulis sebuah teks atau cerita, dan 5) Siswa tidak bersemangat dalam proses pembelajaran menulis.

Selain dari faktor tersebut, permasalahan lain yang ditemukan di dalam pembelajaran menulis adalah pembelajaran yang diterapkan oleh guru masih bersifat konvensional. Metode pembelajaran yang diterapkan oleh guru di dalam kelas merupakan suatu hal yang penting untuk diperhatikan. Pembelajaran yang diterapkan oleh guru cenderung kurang inovatif. Dalam proses pembelajaran di kelas, guru hanya menerapkan metode ceramah dan tanya jawab saja. Pada saat kegiatan pembelajaran menulis, siswa hanya 
diberikan sedikit penjelasan serta contoh yang ada di dalam buku paket yang materinya sangat terbatas. Selain itu, guru juga kurang memberikan latihan rutin dan terbimbing kepada siswa secara lebih mendalam, sehingga hal ini memungkinkan siswa kurang begitu memahami bagaimana cara menulis yang baik, terlebih dalam menulis sebuah cerita fiksi.

Agar dapat mengatasi permasalahan yang terjadi di dalam pembelajaran menulis terutama menulis teks fabel, perlu adanya suatu pemecahan masalah agar kemampuan siswa dalam menulis pada umumnya dapat lebih meningkat lagi dari sebelumnya. Dalam hal ini, peneliti ingin memperbaiki pola pembelajaran menulis menjadi suatu pembelajaran yang inovatif dan menyenangkan. Hal ini bertujuan agar kegiatan menulis teks fabel dapat mengalami peningkatan dari semester yang lalu. Cara yang akan diterapkan oleh peneliti adalah dengan menggunakan pembelajaran berbasis portofolio. Metode pembelajaran berbasis portofolio ini dipilih karena pada dasarnya portofolio berhubungan dengan hasil karya siswa di dalam pembelajaran yang berbentuk lembar kerja. Begitu pula dengan materi teks fabel yang juga menuntut siswa agar dapat menulis teks fabel yang baik dan menarik.

Menurut Sumarna, dkk (dalam Khanifa, 2011: 6) portofolio merupakan kumpulan hasil belajar atau karya peserta didik yang menunjukkan usaha, perkembangan, prestasi belajar peserta didik dari waktu ke waktu dan dari satu mata pelajaran ke pelajaran lain. Portofolio dapat memperlihatkan perkembangan kemajuan belajar siswa melalui karyanya, antara lain: resensi buku, karangan, puisi, gambar, lukisan, foto, laporan penelitian, sinopsis dan sebagainya. Apabila pembelajaran berbasis portofolio ini diterapkan pada materi teks fabel, diharapkan dengan adanya beberapa kumpulan karangan menulis teks fabel siswa, siswa dapat melihat kemajuan atau perkembangan belajar mereka selama di sekolah, sehingga dapat membantu dalam peningkatan kemampuan menulis teks fabel siswa.

Berkaitan dengan pembelajaran portofolio, ada dua penelitian terdahulu yang juga melakukan penelitian mengenai pembelajaran berbasis portofolio untuk meningkatkan kemampuan menulis siswa. Penelitian ini dilakukan oleh Ratna Juita (Universitas Bengkulu) dan Filda Rahmi Khanifa (Universitas Negeri Malang). Penelitian yang dilakukan oleh Ratna Juita berjudul "Peningkatan Kemampuan Menulis Laporan Berbasis Pembelajaran Portofolio pada Siswa Kelas VIII B MTs Negeri 2 Bengkulu". Sedangkan penelitian yang dilakukan oleh Filda Rahmi Khanifa yaitu berjudul "Peningkatan Keterampilan Menulis Pengalaman Pribadi Berbasis Multikultural dengan Sistem Pembelajaran Portofolio pada Siswa Kelas VII 5 SMP Negeri 1 Wiradesa Kabupaten Pekalongan".

Kedua penelitian tersebut menerapkan pembelajaran berbasis portofolio dalam meningkatkan kemampuan menulis siswa. Dari hasil penelitian dinyatakan bahwa dengan menerapkan pembelajaran berbasis portofolio, peningkatan kemampuan menulis siswa cukup signifikan. Artinya adalah dengan menerapkan 
pembelajaran berbasis portofolio ini, kemampuan menulis siswa dapat meningkat menjadi lebih baik. Dalam hal ini, peneliti juga akan menerapkan pembelajaran berbasis portofolio pada keterampilan menulis. Hal ini dilakukan karena peneliti melihat bahwa pembelajaran berbasis portofolio sangat sesuai dengan kegiatan menulis, di mana portofolio sangat berhubungan sekali dengan hasil karya atau lembar kerja siswa yang berbentuk tulisan-tulisan.

Dari penjelasan di atas, maka peneliti merasa perlu melakukan penelitian mengenai pembelajaran berbasis portofolio pada materi penulisan teks fabel. Berdasarkan uraian di atas, tujuan penelitian ini untuk mendeskripsikan secara komprehensif peningkatan kemampuan menulis teks fabel dengan pembelajaran berbasis portofolio pada siswa kelas VIII di SMP Negeri 1 Pondok Kelapa Bengkulu Tengah.

Menurut Tarigan (1982: 21), "menulis ialah menurunkan atau melukiskan lambang-lambang grafik yang menggambarkan suatu bahasa yang dipahami oleh seseorang sehingga orang-orang lain dapat membaca lambang-lambang grafik tersebut kalau mereka memahami bahasa dan gambaran grafik itu". Dapat dikatakan bahwa kegiatan menulis merupakan suatu kegiatan melukiskan lambanglambang grafik sehingga seseorang dapat memahami gambaran grafik tersebut.

Menulis adalah kegiatan yang dilakukan seseorang untuk menghasilkan tulisan (Nurudin, 2007: 4). Sedangkan menurut Marwoto (dalam Dalman, 2014: 4) menjelaskan bahwa menulis adalah mengungkapkan ide atau gagasannya dalam bentuk karangan secara leluasa.
Menulis merupakan salah satu bagian dari empat keterampilan berbahasa yang harus dikuasai oleh seseorang. Menulis bukanlah suatu hal yang mudah. Kegiatan menulis membutuhkan imajinasi yang baik, agar tulisan yang dihasilkan nantinya dapat menarik perhatian pembaca. Di dalam menulis sesuatu, seorang penulis haruslah memperhatikan unsur penulisan serta unsur di luar penulisan.

Portofolio adalah sekumpulan pekerjaan siswa yang dapat menunjukkan kepada mereka (juga bagi yang lain) atas usaha, kemajuan, dan pencapaian mereka dalam bidang studi tertentu, (Genesee dan Upshur, dalam Suwandi, 2011: 110). Sejalan dengan pendapat Genesee dan Upshur, Wahyuni dan Ibrahim (2012: 70) juga berpendapat bahwa portofolio merupakan kumpulan hasil kerja siswa yang menunjukkan atau memperlihatkan hasil pemikiran mereka, minat, hasil usaha, tujuan dan cita-cita mereka dalam berbagai aspek.

Sebagai suatu hal baru dalam proses pembelajaran, model pembelajaran portofolio didasari dan dilandasi oleh beberapa pemikiran, diantaranya yaitu Empat Pilar Pendidikan (learning to do, learning to know, learning to be, and learning to live together), Pandangan Konstruktivisme, dan Democratic Teaching. Sedangkan untuk prinsip dasar dalam pembelajaran portofolio adalah prinsip belajar siswa aktif, kelompok belajar kooperatif, pembelajaran partisipatorik, mengajar yang reaktif, dan prinsip dasar mengajar yang menyenangkan.

Adapun langkah-langkah penerapan pembelajaran berbasis portofolio adalah sebagai berikut: mengidentifikasi masalah yang ada, memilih suatu 
masalah untuk dikaji di kelas, mengumpulkan informasi terkait dengan masalah yang akan dikai, membuat atau menyusun portofolio kelas, menyajikan portofolio atau dengar pendapat, dan melakukan refleksi pengalaman belajar.

Secara etimologis, fabel berasal dari bahasa Latin "fabulat". Cerita fabel merupakan cerita tentang kehidupan binatang yang berperilaku menyerupai manusia (Kemendikbud, 2014: 2). Sejalan dengan pendapat sebelumnya, Sulistyorini (2014: 1) menyatakan bahwa fabel yaitu cerita yang menggambarkan watak dan budi manusia yang pelakunya diperankan oleh binatang (berisi pendidikan moral dan budi pekerti). Fabel dalam sebuah teks mengandung nilai-nilai moral yang dapat diteladani oleh setiap manusia. Segala hal yang mengandung sifat-sifat moral di dalam sebuah teks fabel dapat diambil dan dapat diajarkan kepada setiap siswa.

Di dalam buku paket Bahasa Indonesia kelas VIII, struktur dari teks fabel dibagi menjadi empat bagian, yaitu orientasi, komplikasi, resolusi dan koda. Sedangkan ciri-ciri umum dan karakterstik dari teks fabel adalah: 1) menggunakan tokoh hewan dalam Penceritaannya, 2) Hewan yang sebagai tokoh utama dapat bertingkah laku seperti manusia pada umumnya, 3) menunjukkan penggambaran moral atau Unsur moral dan karakter manusia serta kritik tentang kehidupan di dalam ceritanya, 4) Penceritaannya pendek, 5) Menggunakan pilihan kata yang mudah, dalam cerita fabel, 6) Paling baik dan tepat untuk diceritakan adalah antara karakter manusia yang lemah dan kuat, dan 7) menggunakan setting atau latar alam.
Untuk menghasilkan teks fabel atau cerita moral yang baik, maka seseorang harus memperhatikan bagaimana langkah-langkah dalam menyusun sebuah teks fabel tersebut. Langkah-langkah dalam menyusun atau menulis sebuah teks fabel dapat dilakukan dengan cara: a) Amatilah perilaku hewan yang ada di sekitar lingkungan, kemudian tentukan hal menarik yang dapat diamati sehingga akan menjadi sebuah tema yang menarik pula, b) Mulailah membuat kerangka teks cerita fabel atau moral yang terdiri dari struktur teksnya, c) Buatlah ide pokok atau gagasan yang ingin ditulis di dalam keempat bagian struktut teks tersebut, d) Hubungkan antara ide pokok pada setiap bagian tersebut dengan menggunakan kata hubung, e) Ketika menyusun teks, terapkan unsur kebahasaan seperti ejaan, pilihan kata, tanda baca, dan kalimat, dan f) Setelah berhasil menyusun teks fabel atau moral, baca dan cermati lagi teks tersebut. Lengkapi kekurangan dan kesalahan yang ada apabila terjadi kesalahan.

\section{METODE PENELITIAN}

Jenis penelitian ini adalah penelitian tindakan kelas dengan menggunakan metode deskriptif. Menurut Susetyo (2010: 89) PTK merupakan suatu kajian yang bersifat reflektif sebagai upaya untuk memperbaiki keadaan (proses) atau memecahkan masalah yang dihadapi, dan juga mencari kebenaran secara praktis. Penelitian ini dilaksanakan di SMP Negeri 1 Pondok Kelapa Bengkulu Tengah. di. Subjek penelitian ini adalah siswa-siswi kelas VIII F SMP Negeri 1 Pondok Kelapa Bengkulu Tengah. Data 
dalam penelitian ini diuraikan secara kualitatif berdasarkan lembar observasi (pengamatan), lembar jurnal siswa dan guru, lembar pedoman wawancara, dan hasil tes menulis. Untuk data hasil belajar diperoleh dari tes unjuk kerja yang berupa kegiatan menulis teks fabel.

Data di dalam penelitian ini adalah teks fabel yang ditulis oleh siswa, sedangkan sumber datanya berupa lembar kerja siswa dalam menulis teks fabel. Penelitian ini dilaksanakan dalam tiga siklus. Siklus I dan siklus II dilaksanakan dalam dua kali pertemuan, sedangkan pada siklus III dilaksanakan dalam satu kali pertemuan. Setiap siklus terdiri dari empat kegiatan, yaitu 1) Perencanaan, 2) Tindakan, 3) Observasi, dan 4) Refleksi. Teknik analisis data yang digunakan pada penelitian ini adalah dengan teknik kuantitatif dan kualitatif.

\section{HASIL DAN PEMBAHASAN}

\section{Siklus I}

Dalam pelaksanaan kegiatan pembelajaran pada siklus I ini, peneliti terlebih dahulu mempersiapkan semua perangkat pembelajaran yang dibutuhkan. Perangkat pembelajaran tersebut terdiri atas RPP, aspek penilaian, menyusun lembar observasi, pedoman wawancara, serta lembar jurnal siswa dan guru. Tindakan pembelajaran pada penelitian siklus I ini dilaksanakan sebanyak dua kali pertemuan atau tatap muka. Kegiatan pembelajaran pada pertemuan pertama dilaksanakan pada 19 Agustus 2015 (12.00-13.20 WIB).

Kegiatan siswa dalam proses pembelajaran pada pertemuan pertama adalah: 1) Siswa mengamati dan memahami teks fabel dengan cermat dan teliti, 2) Guru menjelaskan materi teks fabel yang berhubungan dengan struktur pembangun teks dan unsur kebahasaan, 3) Siswa membentuk kelompok yang anggotanya masingmasing berjumlah 5 orang, 4) Setiap kelompok ditugaskan untuk menentukan topik dan struktur dari teks fabel yang berjudul "jiji jerapah dan kus tikus", 5) Siswa mengomunikasikan kembali hasil pekerjaannya di depan kelas, 6) Siswa menyampaikan hambatan yang dialami ketika mengklasifikasi teks fabel dan mendengarkan umpan balik dan penguatan dari guru, dan 7) Tugas kelompok siswa dikumpulkan menjadi satu bundel dalam map guru.

Kegiatan siswa pada pertemuan selanjutnya dilaksanakan pada 20 Agustus $2015 \quad$ (09.45-11.05 WIB). Pembelajaran pada pertemuan kedua di siklus I ini adalah: 1) Siswa membaca teks fabel dengan cermat dan teliti, 2) Guru memancing pemahaman ciswa dan melakukan kegiatan tanya jawab, 3) Siswa memperhatikan tahap-tahap dalam menulis teks fabel dan membuat garis besar cerita, 4) Siswa menentukan tokoh hewan yang akan memerankan karakter tokoh yang tertulis pada pokokpokok peristiwa, 5) Siswa mengembangkan pokok-pokok peristiwa dan karakter tokoh, 6) Perwakilan dari siswa membacakan hasil kerjanya di depan kelas dengan penghayatan dan ekspresif, 7) Siswa menyampaikan hambatan yang dialami ketika menulis teks fable serta mendengarkan umpan balik dan penguatan dari guru, dan 8) siswa mengumpulkan tugas (portofolio kelas) di dalam map guru.

Pada tahap pengamatan (observasi) yang dilakukan oleh observer terhadap guru ketika menerapkan 
pembelajaran berbasis portofolio ini di kelas diperoleh bahwa guru kurang bisa menguasai kelas dengan baik, sehingga kegiatan pembelajaran yang berlangsung kurang mendapat perhatian dari siswa. Ketika menulis teks fabel, ada beberapa siswa yang sibuk bertanya kepada sesama rekannya mengenai tugas yang diberikan oleh guru. Siswa tersebut terlihat bingung ketika ditugaskan guru dalam menulis teks fabel. Dalam hal ini, tampaknya guru juga kurang jelas dalam memberikan tugas, sehingga siswa mengalami kesulitan dan terlihat bingung ketika mengerjakannya.

Berdasarkan hasil tes yang telah dilakukan oleh peneliti, maka diperoleh nilai rata-rata kelas sebesar 63,6 dengan kategori cukup dan persentase kelulusan siswa hanya mencapai $27 \%$. Sedangkan untuk hasil setiap aspek, diperoleh skor sebagai berikut: a) penalaran dan kelengkapan struktur teks diperoleh skor sebesar 3,3 (66\%) dengan kategori cukup, b) kaidah kebahasaan diperoleh skor sebesar 4,1 (82\%) dengan kategori baik, c) penggunaan EYD diperoleh skor sebesar 1,5 (29,3\%) dengan kategori sangat kurang, dan d) kerapian teks diperoleh skor sebesar 3,3 (66,7\%) dengan kategori cukup.

Kegiatan menulis teks fabel dengan pembelajaran berbasis portofolio pada siklus I ini merupakan suatu upaya dalam meningkatkan kemampuan menulis teks fabel siswa. Berdasarkan hasil pengamatan (observasi), dapat disimpulkan bahwa pelaksanaan tindakan pada siklus I belum berhasil. Maka dari itu, perlu dilakukannya tindakan pada siklus berikutnya, yaitu siklus ke II. Hal ini bertujuan agar kemampuan menulis teks fabel siswa dapat lebih meningkat lagi dari siklus I.
Ada beberapa temuan ataupun kendala yang peneliti temui pada pelaksanaan tindakan di siklus I. Kendala tersebut adalah: 1) Kurangnya perhatian siswa terhadap penjelasan guru selama proses pembelajaran berlangsung. 2) Di dalam proses pembelajaran, guru kurang menguasai kelas dengan baik. 3) Pembelajaran berbasis portofolio di dalam kegiatan menulis teks fabel ini berlangsung ketika suasana di sekitar kelas tidak kondusif, sehingga hal ini menyebabkan siswa tidak dapat berkonsentrasi dengan baik. 4) Aspek penggunaan EYD perlu mendapatkan perhatian lebih dari guru, agar siswa dapat lebih memahami tentang penggunaan EYD di dalam sebuah tulisan.

\section{Siklus II}

Perencanaan pelaksanaan kegiatan pembelajaran pada siklus II ini dilakukan oleh peneliti dengan terlebih dahulu mempersiapkan semua perangkat pembelajaran yang dibutuhkan. Perangkat pembelajaran tersebut secara umum tidak jauh berbeda atas siklus I, yaitu RPP, aspek penilaian, menyusun lembar pengamatan (observasi), pedoman wawancara, serta lembar jurnal siswa dan guru.

Pertemuan pertama pada siklus II ini dilaksanakan pada tanggal 24 Agustus (09.45-11.05 WIB). Adapun rangkaian kegiatan yang terdapat pada siklus ke ii pertemuan pertama ini adalah sebagai berikut: 1) Siswa mengamati lembar kerja yang telah dibagikan oleh guru dengan cermat, 2) Guru menjelaskan mengenai penggunaan eyd di dalam sebuah tulisan, 3) Siswa secara individu ditugaskan untuk mengerjakan latihan di 
dalam buku paket bahasa indonesia, dan 4) Setiap siswa menyampaikan hambatan yang dialami ketika menyusun dan mengidentifikasi teks fabel.

Selanjutnya rangkaian kegiatan pembelajaran pada pertemuan kedua ini adalah 1) Guru menjelaskan kembali tipstips dalam menulis teks fabel, 2) Guru memperlihatkan kepada siswa contoh gambar hewan-hewan yang hidup di darat dan di air, 3) Siswa membuat garis besar cerita dengan menuliskan pokokpokok peristiwa, 4) Siswa menentukan tokoh hewan yang akan memerankan karakter tokoh serta mengembangkan pokok-pokok peristiwa dan karakter tokoh ke dalam beberapa kalimat, 5) Siswa membacakan hasil kerjanya di depan kelas dengan penghayatan dan ekspresif, 6) Siswa menyampaikan hambatan yang dialami ketika menulis teks fabel dan mendengarkan umpan balik dan penguatan dari guru, 7) siswa mengumpulkan lembar kerjanya di dalam map guru.

Berdasarkan hasil tes menulis yang telah dilakukan pada siklus II ini, maka diperoleh nilai rata-rata kelas sebesar 70, dengan kategori baik dan persentase kelulusan siswanya mencapai $56,7 \%$. Secara keseluruhan, terdapat 17 orang siswa yang lulus atau memenuhi nilai KKM sebesar 70, sedangkan 13 orang lainnya belum memenuhi KKM. Jadi, untuk rata-rata kelas sebesar 75 (kategori baik) yang telah ditetapkan oleh peneliti belum juga tercapai pada siklus II ini.

Selain itu, skor setiap aspek yang diperoleh siswa adalah sebagai berikut: a) Penalaran dan kelengkapan struktur teks diperoleh skor sebesar 3,8 (76\%) dengan kategori baik, b) Kaidah kebahasaan diperoleh skor sebesar 4,2
(84\%) dengan kategori baik, c) Penggunaan EYD diperoleh skor sebesar $2,1 \quad(42,7 \%)$ dengan kategori sangat kurang, dan d) kerapian teks diperoleh skor sebesar 3,4 (67,3\%) dengan kategori cukup.

Berdasarkan diskusi peneliti dengan observer, masalah yang ditemui pada siklus ke II ini adalah ketidak pahaman siswa terhadap aspek penilaian penggunaan EYD di dalam sebuah tulisan. Kemungkinan lain yang dapat diperoleh dari ketidakpahaman siswa dalam penggunaan EYD ini adalah siswa tidak dapat mengaplikasikan penjelasan yang diberikan oleh guru ke dalam suatu tindakan yang nyata, seperti ketika mereka menulis sebuah teks fabel.

Masalah yang ditemukan oleh peneliti dan observer pada siklus II ini akan ditindaklanjuti lagi pada siklus berikutnya, sehingga peneliti memutuskan untuk melanjutkan penelitian tindakan kelas ini pada siklus ke III. Tindakan pada siklus III ini dilakukan agar hasil tes kemampuan menulis teks fabel siswa yang sebelumnya hanya sebesar 70 (baik) dapat meningkat dan memenuhi target nilai rata-rata yaitu 75 .

\section{Siklus III}

Rangkaian kegiatan pada tahap perencanaan ini tidak jauh berbeda dari perencanaan di siklus I dan siklus II. Perencanaan pembelajaran yang dilakukan oleh peneliti adalah mempersiapkan perangkat pembelajaran (RPP), mempersiapkan lembar observasi, pedoman wawancara, serta lembar jurnal siswa dan guru.

Adapun kegiatan pembelajaran pada penelitian di siklus III ini adalah sebagai berikut: 1) Guru menjelaskan 
materi dan memancing pemahaman siswa terhadap materi yang telah diajarkan sebelumnya, 2) Siswa bertanya jawab mengenai penilaian yang telah diberikan oleh guru pada siklus ii, 3) Siswa menulis kembali teks fabel dengan tema dan judul yang baru, 4) Siswa mengomunikasikan cerita fabel di depan kelas, 5) Siswa diminta untuk menyampaikan hambatan yang dialami ketika menulis teks fabel pada siklus iii ini, 6) Siswa mengumpulkan lembar kerja di dalam map guru (portofolio).

Kegiatan pembelajaran yang berlangsung pada siklus III ini ternyata menunjukkan respon yang sangat baik dari siswa. Siswa terlihat sangat serius, bersemangat dan antusias dalam mengikuti pembelajaran. Perhatian siswa pun terhadap guru juga sangat baik dari dua siklus sebelumnya. Selain itu, siswa juga aktif bertanya seputar teks fabel yang telah mereka tulis dan diberi penilaian serta catatan oleh guru. Hal ini disebabkan oleh karena mereka ingin memperbaiki teks fabel yang telah mereka tulis. Selain itu, siswa juga termotivasi untuk mendapatkan nilai yang lebih bagus dari sebelumnya.

Setelah peneliti dan observer melakukan penilaian terhadap hasil kegiatan menulis teks fabel siswa pada sklus III ini, maka diperoleh nilai rata-rata kelas sebesar 76 dengan kategori baik. Secara keseluruhan, terdapat 26 orang siswa yang lulus atau dengan persentase sebesar $86,7 \%$. Nilai ini telah memenuhi nilai KKM sebesar 70, sedangkan 4 orang lainnya belum memenuhi KKM, tetapi berada pada kategori cukup. Jadi, untuk rata-rata kelas sebesar 75 (kategori baik) telah dicapai pada siklus III ini, walaupun peningkatan tersebut tidak terlalu signifikan dari target rata-rata kelas yang telah ditetapkan. Oleh sebab itu, penelitian tindakan kelas yang dilakukan oleh peneliti pada siklus III ini dinyatakan selesai dan tidak perlu dilanjutkan lagi.

Kemudian, untuk skor setiap aspek yang diperoleh siswa adalah sebagai berikut: a) Penalaran dan kelengkapan struktur teks diperoleh skor sebesar 3,9 (77,3\%) dengan kategori baik, b) Kaidah kebahasaan diperoleh skor sebesar 4,5 $(90,7 \%)$ dengan kategori sangat baik, c) Penggunaan EYD diperoleh skor sebesar 2,5 (50,7\%) dengan kategori kurang, dan d) Kerapian teks diperoleh skor sebesar 4 (80\%) dengan kategori baik.

Peningkatan kemampuan menulis teks fabel di setiap siklusnya dapat dilihat pada halaman berikut.

Berdasarkan hasil nilai rata-rata pada setiap aspek di atas, dapat diperoleh bahwa nilai rata-rata kemampuan menulis teks fabel siswa pada siklus I diperoleh rata-rata sebesar 63,6 dengan kategori cukup. Nilai ratarata yang diperoleh pada siklus II yaitu sebesar 70 dengan kategori baik. Sedangkan nilai rata-rata yang diperoleh pada siklus III yaitu sebesar 76 dengan kategori baik. Kemudian untuk peningkatan tahap awal atau prasiklus ke siklus I yaitu sebesar 8,7. Lalu peningkatan dari siklus I ke siklus II yaitu sebesar 6,4. Sedangkan peningkatan dari siklus II ke siklus III sebesar 6 . 
Tabel Peningkatan Kemampuan Menulis Teks Fabel Siklus I, Siklus II, dan Siklus III

\begin{tabular}{|c|c|c|c|c|c|c|}
\hline \multirow{2}{*}{ Aspek } & \multicolumn{2}{|l|}{ Rata-rata } & \multicolumn{2}{l|}{ Peningkatan } \\
\cline { 2 - 7 } & S I & S II & S III & S I-S II & S II-S III & Peningkatan \\
\hline $\mathbf{1}$ & 66 & 76 & 77,3 & 10 & 1,3 & $4,3 \%$ \\
\hline $\mathbf{2}$ & 82 & 84 & 90,7 & 2 & 6,7 & $22,3 \%$ \\
\hline $\mathbf{3}$ & 29,3 & 42,7 & 50,7 & 13,4 & 8 & $26,7 \%$ \\
\hline $\mathbf{4}$ & 66,7 & 67,3 & 80 & 0,6 & 12,7 & $42,3 \%$ \\
\hline
\end{tabular}

Berdasarkan hasil tindakan pembelajaran pada siklus III ini, diperoleh bahwa pembelajaran berbasis portofolio yang diterapkan oleh peneliti mampu meningkatkan hasil tes kemampuan menulis teks fabel siswa. Hal ini dapat dilihat dari nilai rata-rata kelas yang diperoleh, yaitu sebesar 76 dan dalam kategori baik, serta persentase kelulusan siswa mencapai $86,7 \%$. Rata-rata 76 ini telah melampaui target rata-rata yang telah ditetapkan yaitu sebesar 75. Di sini terlihat ada peningkatan yang cukup signifikan dari siklus II.

Dengan diperolehnya rata-rata kelas sebesar 76 ini dan terlampauinya target rata-rata kelas sebesar 75 pada siklus III ini, maka peneliti memutuskan bahwa penelitian tindakan kelas ini tidak dilanjutkan lagi ke siklus berikutnya. Karena pada siklus ke III, nilai rata-rata siswa dapat tercapai dan terlampaui dengan baik.

\section{SIMPULAN}

Berdasarkan penelitian yang telah dilakukan oleh peneliti, maka dapat disimpulkan bahwa dengan menerapkan pembelajaran berbasis portofolio, kemampuan siswa kelas VIII dalam menulis teks fabel mengalami peningkatan yang signifikan. Peningkatan hasil tes siswa pada siklus I yaitu sebesar 63,6 (cukup) dengan persentase kelulusan siswa sebesar $27 \%$. Pada siklus II meningkat menjadi 70 (baik) dengan persentase kelulusan sebesar $56,7 \%$. Begitupun di siklus III. Peningkatan yang terjadi yaitu sebesar 76 (baik) dengan persentase kelulusan siswanya mencapai $86,7 \%$.

Berdasarkan simpulan di atas, maka disarankan: 1) Guru mata pelajaran bahasa indonesia hendaknya dapat menerapkan pembelajaran berbasis portofolio ini di dalam kegiatan atau materi menulis. 2) Bagi para peneliti, penerapan pembelajaran berbasis portofolio sangatlah sesuai dengan kemampuan menulis. Keuntungan dari penerapan pembelajaran berbasis portofolio ini pada pembelajaran menulis adalah dapat meningkatkan kemampuan menulis siswa dan dapat pula menciptakan suasana belajar yang menyenangkan bagi siswa. 3) Keterbatasan yang ditemui dan dihadapi oleh peneliti terutama dalam hal meningkatkan kemampuan siswa pada aspek penggunaan EYD, maka peneliti berharap agar peneliti lain dapat melakukan penelitian lanjutan dari penelitian ini. 


\section{DAFTAR PUSTAKA}

Dalman. 2014. Keterampilan Menulis. Jakarta: PT Raja Grafindo Tinggi.

Mahsun. 2014. Teks dalam Pembelajaran Bahasa Indonesia Kurikulum 2013. Jakarta: PT RajaGrafindo Persada.

Khanifa, Filda Rahmi. 2011. Peningkatan Keterampilan Menulis Pengalaman Pribadi Berbasis Multikultural dengan Sistem Pembelajaran Portofolio pada Siswa Kelas VII 5 SMP Negeri 1 Wiradesa Kabupaten Pekalongan. Universitas Negeri Semarang.

Nurudin. 2010. Dasar-Dasar Penulisan. Malang: UMM Press.

Sulistyorini, Dwi. 2014. Kriteria Pemilihan Materi Ajar Teks Moral/Fabel Pelajaran Bahasa Indonesia dalam Kurikulum 2013. Universitas Negeri Malang.
Susetyo. 2010. Penelitian Kuantitatif dan Penelitian Tindakan Kelas. Universitas Bengkulu.

Suwandi, Sarwiji. 2011. Model Asesmen dalam Pembelajaran. Surakarta: Yama Pustaka.

Tarigan, Henri Guntur. 1982. Menulis Sebagai Suatu Keterampilan Berbahasa. Bandung: Angkasa.

Wahyuni, Sri dan Syukur Ibrahim. 2012. Asesmen Pembelajaran Bahasa. Bandung: PT Refika Aditama.

Wahyuni, Sri dan Abdul Syukur Ibrahim. 2013. Model Penilaian Hasil Belajar Peserta Didik. Kementerian Pendidikan dan Kebudayaan, Direktorat Jenderal Pendidikan Menengah, Direktorat Pembinaan SMA. 